\title{
The predictability of financial, accounting-based, and industrial factors on the success of newly incorporated Spanish firms
}

\author{
Yehui Tong (iD, Ramon Saladrigues (D) \\ Faculty of Law, Economics and Tourism, Department of Business Administration and Economic Management of Natural \\ Resources, University of Lleida (Spain) \\ tongyyhb@163.com,ramon.saladrigues@aegern.udl.cat
}

Received July, 2017

Accepted January, 2018

\section{Abstract}

Purpose: The purpose of this paper is to identify the impacts and predictability of financial, accounting-based, and industrial factors (as well as corporate venturing) on survival-based success of newly incorporated firms in Spain.

Design/methodology: Logistic regression is used for comparing the differences of factors in the prediction of future success after different time periods since the studying years (age 1, age 2, and age 3 respectively) in manufacturing and distributive sectors.

Findings: Differences in predictability are observed between manufacturing and distributive sectors: it is obvious in distributive sector (rather than manufacturing sector) that liquidity, bank credit, trade credit, and concentration are positively related to success while entry rate is negatively related to success. In spite of that, some factors still show strong predictability in both two sectors. Firm size and profitability are the strongest positive factors, which are followed by corporate venturing and the growth of industrial operating revenues with positive and generally negative relationships to success separately. Besides, for some factors and variables frequently showing statistical significance, their impacts in the same age tend to be relatively stable.

Practical implications: The findings of this paper can help to identify the predictability of different factors on the success of newly incorporated firms and catch the differences between manufacturing and distributive sectors.

Originality/value: This paper enriches the empirical study of new firm success in Spain in depression and stagnant environment (because the observed years here are from 2009 to 2014); besides, the findings also contribute to the specific prediction study of manufacturing and distributive sectors.

Keywords: Survival-basedsuccess, Financial, Accounting-based and industrial factors, Predictability

Jel Codes: M13, L60, L81 


\section{Introduction}

Entrepreneurship is a hot research topic attracting scholars by virtue of its significant influence on economy. Positive effects of entrepreneurship on employment growth in pan-European regions are advocated by Doran McCarthy and O'Connor (2016); Vázquez-Rozas, Gómes and Vieira (2010) believe that GDP (gross domestic product) growth would be positively impacted by entrepreneurship in Spanish and Portuguese regions. The research on entrepreneurship is from miscellaneous facets; however, just as Amason, Shrader and Tompson (2006) highlight, the core of entrepreneurship is to explore and explain the issue of new venture success and failure.

Murphy, Trailer and Hill (1996) summarize eight performance dimensions, and success (or failure) is just one of them; in addition, several different criteria for measuring success or failure are also listed in that research. Brüderl and Preisendörfer (1998) too believe success can be measured from different dimensions and they further point out that survival should be the minimum standard in measuring success. In fact, of great importance is the issue of survival or failure to entrants or new firms: for example, after doing research on 10 OECD (The Organisation for Economic Co-operation and Development) countries, Bartelsman, Scarpetta and Schivardi (2005) find that 20 to 40 percent of entrants suffer failure in the first two years and the survival rate is between 40 and 50 percent after seven years.

As for new firm success and failure, plenty of research has tried to explore the roots of them. Liability of newness (Stinchcombe, 1965) and liability of smallness (Aldrich \& Auster, 1986) separately attribute the failure of new firms and small firms to age and size factors, as is described by Mellahi and Wilkinson (2004) in their paper. Jovanovic (1982) proposes a frequently cited selection theory: that is, efficient firms outperform inefficient ones in survival and growth, and the efficiency of a firm would be learned after its operation. Like other researchers, Lotti and Santarelli (2004) discriminate the theory of Jovanovic (1982) and the theory of Ericson and Pakes (1995) separately as passive learning and active learning in their research where the theory of Ericson and Pakes (1995) is summarized as firms' decisions for maximizing the expected value with knowing the characteristics of themselves and competitors and the future distribution of industry structure.

There are also different views about the determinants of firm performance: the resource-based view focuses on the internal sources of a firm's sustained competitive advantage whereas the industrial organization view highlights the impacts of outside industry structure (Kraaijenbrink, Spender \& Groen, 2010). Chrisman, Bauerschmidt and Hofer (1998) divide the influence of industry structure into two types: absolute and relative affects. In particular, on the ground of previous literature, they list three dimensions of impacts from the angle of absolute or average profit potential and expected returns to explain the attractiveness of industry: the impacts of structural barriers and gateways on the difficulty to enter, the impacts on remaining business during its vulnerable period in competition, and the impacts on the availability of resources for survival in industry; as for relative affect, they illustrate it as the opportunities generated by industry structure and the ability of ventures to catch these opportunities with using their resources to create value.

The purpose of this paper is to explore the predictability of financial, accounting-based, and industrial factors (as well as corporate venturing) on survival-based success after different periods since the studying years. The standard for judging success or not is whether a firm does not report operating revenues in two consecutive years, which is similar to the survival-judging method used by Fotopoulos and Louri (2000). So the criterion for separating success and failure here can be seen as being built on the survival status of a firm (or based on the record of generating operating revenues), which is backed up by the viewpoint of survival as the minimum standard for success (Brüderl \& Preisendörfer, 1998), the emphasis of market nexus in performance evaluation (Reid and Smith, 2000), and the statement of Stearns, Carter, Reynolds and Williams (1995) that new firms are more likely to discontinue operations.

One feature of this paper is to compare the impacts of factors in two sectors (manufacture and distribution section C and G of NACE Rev. 2 from Eurostat of European Commission, 2008), which would contribute to industrial sector research. Another feature is that the selected samples (including the firms incorporated in 2008 
and 2009) proffer a chance to observe the impacts and predictability of factors in crisis period. So the results could also enrich the empirical study of new firm performance in depression and stagnant environment. The followings of this paper are organized in this order: Section 2 reviews the related literature and proposes the hypotheses; Section 3 explains the research method together with the selection of data and variables; Section 4 shows the regression results; Section 5 concludes the whole paper with implications and suggestions for future research.

\section{Literature review and hypotheses}

Firm size is an important factor in the research of performance. Generally, compared to existing firms, new firms tend to be smaller in size. Mata and Portugal (2002) summarize three reasons on the ground of past literature to explain the phenomenon that new firms generally show smallness in firm size: being small can help new firms shun the aggression of existing firms; being small can help new firms reduce losses if happening; and insufficiency in funds is an objective reason that causes smallness of new firms.

Audretsch (1991) proposes inherent size disadvantage which is explained by Audretsch and Mahmood (1995) as cost disadvantage and exposure to risk impacting much on new business survival. Cincera and Galgau (2005) also state the phenomenon that showing smaller size than industry average or efficient scale is a feature of exiting firms. However, it does not mean that there is no advantage to small size. Brüderl, Preisendörfer and Ziegler (1992) list the advantages of both large and small new firms: large firms have more financial resources to support start-up period and for against environmental shocks as well as advantages in the facets of capital, tax and labor, while less overhead costs and less resources for sustenance are the advantages of small ones.

Positive effect of size on survival is found in plenty of past empirical research (Görg \& Strobl, 2003); notwithstanding that, no consensus has been reached. Agarwal and Audretsch (1999) find that the impacts of size on start-up survival are different in different life-cycle stages: in the formative stages the survival rates of larger start-ups are higher than those of smaller ones whereas in the mature stages small firms do not incur size disadvantage in survival because of occupying strategic niche. The research results of Santarelli and Vivarelli (2007) show that start-up size is not positively related to survival in any industrial sector and the significance is also a problem. So it is necessary to do research in different industry sectors, and this paper studies manufacturing and distributive sectors.

As for market share, there should exist some linkages between it and firm size, because it is possible that the firms being larger in size would have stronger productivity and more output which would help them occupy higher market share. Geroski (1995) points out that, compared to relatively higher entry rate, the proportion of the total sales of entrants to that of the whole industry should be lower and this could be explained by relatively smaller size of entrants to incumbents. In fact, market share could be viewed as a positive factor on performance. Laverty (2001) states that positive relationship between market share and profitability as mainstream conclusion has been supported since 1970s by Gale (1972) for example. Despite that, different viewpoints also emerge in the research of, for instance, Bourantas and Mandes (1987) pointing out the complexity of research where multiple impacting factors should be considered as well as Fraering and Minor (1994) who also highlight the heterogeneity between industries.

\section{Hypothesis 1: Firm size is a positive indicator to success.}

\section{Hypothesis 2: Market share is a positive indicator to success.}

There is no much doubt that profit is a key factor attracting entrepreneurs to start up business. Profits and losses are separately the important reasons for entry and exit (Ilmakunnas \& Topi, 1999). Santarelli and Vivarelli (2007), with the support of previous literature, list two important factors spurring the establishment of new firms: profit expectations and advantageous economic conditions. Fritsch, Brixy and Falck (2006) believe that one of the reasons for the failure of new firms is the existence of a certain time period of surviving to gain profits. So new firms may not get profits at beginning. Furthermore, Audretsch (1995) states that, even if in the situation of suffering economic losses, firms may stay operating and keep positive output if with the expectation of gaining 
profits in the future. Empirical studies, for example the research of Delmar, McKelvie and Wennberg (2013), are also in favor of positive effects of profitability.

\section{Hypothesis 3: Profitability is a positive indicator to success.}

The door of the research on modern theory of capital structure and financing was opened by Modigliani and Miller (1958) when publishing their irrelevancy theory of capital structure (Harris \& Raviv, 1991; Ardalan, 2017). Myers (2001) in his paper negates the expectation of universality in the theory of debt-equity choice and lists some well-known ones. Among the theories enumerated by Myers (2001), two are often compared by scholars for example by López-Gracia and Sogorb-Mira (2008): trade-off theory which highlights the balances between tax advantages and the costs of financial distress as well as agency costs (Jensen \& Meckling, 1976), and, pecking order theory - proposed by Myers and Majluf (1984) and Myers (1984) — which stresses the priority of borrowing than issuing equity in the situation of insufficiency of internal cash flow.

In fact, not only are the theories about capital structure diversified, but also difference exists in the empirical study of its impacts. For example, Nunes and Serrasqueiro (2012) find that debt is positively related to survival for both young and old SMEs (small and medium-sized enterprises), particularly the young. By contrast, negative relationship between leverage and survival is supported by Baggs (2005).

Robb and Robinson (2014) point out the most important three financing sources of start-ups: bank debt, personal equity and trade credit. Positive effects of bank finance or bank loans on survival are found in the research of, for example, Saridakis, Mole and Storey (2008), as well as Åstebro and Bernhardt (2003) who further highlight "ceteris paribus" for getting the positive effects but showing negative relationship if unconditional. Bastié, Cieply and Cussy (2011) propose a relatively complex conclusion that bank debt would insignificantly or negatively impact new firm survival within two years but positively influence survival beyond two years in the medium term.

The use of trade credit is composed of two parts: receiving it as accounts payable and supplying it as accounts receivable (Ferrando \& Mulier, 2013). In some European countries like Spain and France, accounts receivable or accounts payable occupies a considerable proportion of assets (García-Teruel \& Martínez-Solano, 2010). Petersen and Rajan (1997) list three main reasons for proffering trade credit which constitute its pedestal: financing with cost advantage (in getting information, controlling, and the situation of default), price discrimination, and decreasing transaction costs.

Compared to bank credit, the size of trade credit is much larger especially in smaller firms (Wilson \& Summers, 2002). The research of Huyghebaert (2006) as well as Huyghebaert and Van de Gucht (2007) shows that: high failure rates, as one of the features of start-ups, would cause limitations for start-ups to get bank loans, thus relying on supplier financing (although this relationship may change as time goes by); financial constraints, no history, and no established relationships with banks and suppliers also promote the use of trade credit; and private benefits of control (featured as highly concentrated ownership in start-ups) could be a reason for entrepreneurs to decrease the reliance on bank debt when starting up.

Although the theoretical significance of trade credit has been stressed by academicians, in empirical study the effects of trade credit on firm performance should be gauged with considering different situations. For example, Martínez-Sola, García-Teruel and Martínez-Solano (2014) find that investing in trade credit is positively related to profitability but not for the firms with less market share and those without reputation. Researching on accounts receivable and payable is also contained in the literature of bootstrapping: for instance, Rutherford, Coombes and Mazzei (2012) find that accounts receivable is negatively related to survival.

Hypothesis 4: Indebtedness is a negative indicator to success.

Hypothesis 5: Bank debt is a positive indicator to success.

Hypothesis 6: Accounts receivable is a negative indicator to success. 


\section{Hypothesis 7: Accounts payable is a positive indicator to success.}

Liquidity and efficiency indicators usually appear in the research of predicting bankruptcy and business failure. For example, in the well-known Altman's Z-score (Altman, 1968), working capital to total assets and sales to total assets are employed in the prediction formula separately as the proxies of liquidity ratio and the ability to generate sales; in fact, except for working capital to total assets, Altman (1968) also considers two other candidate liquidity ratios (current ratio and quick ratio) and Altman, Haldeman and Narayanan (1977) choose current ratio in their developed formula. Another popular predicting model besides Altman's Z-Score (Altman, 1968), as is said by Hillegeist, Keating, Cram and Lundstedt (2004), is Ohlson's O-Score (Ohlson, 1980) where working capital to total assets and current liabilities to current assets are included in the model. Laitinen (1992) also identifies the ability to generate revenues and liquidity (which is further divided into dynamic liquidity and static liquidity) as important factors to predict the failure of new firms.

Although liquidity is popularly used, its impacts on performance may be a little complex. Based on previous literature, Serrasqueiro and Nunes (2008) on the one hand summarize some reasons for positive effects of liquidity on performance, like advancing the capacity to deal with changes of competitive markets and the importance for meeting short-term commitment; on the other hand they point out theoretical possibility for negative relationship between liquidity and performance, which may come from the conflicts between owners and managers. The predictability of asset rotation on failure is also challenged by Charitou, Neophytou and Charalambous (2004) due to their findings of statistical insignificance.

\section{Hypothesis 8: General liquidity is a positive indicator to success.}

\section{Hypothesis 9: Asset rotation is a positive indicator to success.}

Corporate venturing as an academic topic has been developed since 1960s (Hill \& Birkinshaw, 2008). Although there is no one fully agreed definition of corporate venturing, its characteristics are agreed: developing a new business entity and highly innovative business model (Reimsbach \& Hauschild, 2012). Bierwerth, Schwens, Isidor and Kabst (2015) believe that corporate venturing (as one of the three means of corporate entrepreneurship strategic renewal, innovation, and corporate venturing) can help firms diversify business structures and products market area when venturing in new industrial segments. And the purpose of venturing is to enhance profitability and competitiveness (Zahra, 1993).

Theoretically speaking, corporate ventures should have some advantages that do not exist in independent ventures, but whether these can help corporate ventures much still deserves to be empirically studied. Shrader and Simon (1997) state that corporate ventures are relatively easier to gain more resources by virtue of sponsoring from parent companies (whereas independent ventures are hindered by liability of newness to gain resources), and internal and external capital resources are separately highlighted by corporate ventures and independent ventures; they further find that, notwithstanding the differences of resources and strategies of the two types of ventures, difference in performance is not supported. In fact, independent ventures also have their advantages: the study of Zahra and George (1999) points out that, though independent ventures are constrained to obtain resources, advantages can come from decision-making process where there is direct and active involvement of owners.

On the other hand, Bridges and Guariglia (2008) use group dummy variable to identify whether a firm belongs to a group, and they find positive relationship between being part of a group and survival. Disney, Haskel and Heden (2003) document that single establishments show lower survival rate than group establishments do as time goes by; and, after researching in depth, they find that the characteristics related to whether belonging to a group (rather than belonging to a group per se) are crucial to relative hazard.

\section{Hypothesis 10: Corporate venturing is a positive indicator to success.}

Segarra and Callejón (2002) believe that industry entry rate can represent both barriers to entry and competition: in particular, high entry rate means low level of entry barrier and high degree of competition; on the other hand, their findings also show that even in the industries with high competition or with significant barriers high entry 
rate still appears. Regarding entry barrier, though the linkage between entry barrier and exit barrier is supported by for example Fotopoulos and Louri (2000) with the case of sunk cost, according to the study of McAfee, Mialon and Williams (2004) whether sunk cost per se (as well as economies of scale and capital requirements) can be classified as entry barrier is an arguing point because of different definitions of entry barrier.

Fritsch et al. (2006) too deem that high entry rate signifies more intensity of competition which would lead to new firm failure. In fact, correlation between entry rate and exit rate is observed in the literature (for example, in the research of Disney et al. (2003)). The explanation of the relationship between high entry rate and high exit rate can be found in the paper of Geroski, Mata and Portugal (2010) where the viewpoints of organization ecology are summarized as follows: high exit rates are the results of the increased density in the market that is caused by high entry rate; as for the entrants in the industries with high entry rates, competition faced by them would be firstly with other entrants, rather than incumbents.

Robinson (1999) believes: industry concentration should be ranked as the first important factor in the research of industrial organization; and low concentration industries absorb most of new ventures, which means that low concentration works as a necessary but not sufficient condition on successful entry. Mata and Portugal (2002) state the theoretical impacts of industry concentration on entrants from both the perspectives of organizational ecology and industrial organization: in organizational ecology literature, competition is a crucial factor that determines surviving or not and, in the industries with less number of firms, increasing density would be beneficial to survival at first but would be disadvantageous to survival if beyond a certain level (because of raising competition); on the other hand, industrial organization academicians believe that collusion would be resulted from market concentration and, in the industries with high concentration, it is more probable that entrants are attacked by existing firms.

From the angle of empirical study, the impacts of concentration on new venture performance are uncertain because three different results (positive, negative and no statistically significant relationships) are all found in past empirical research (Robinson, 1999). Baggs (2005) finds that industry concentration is a negative factor to survival whereas Audretsch (1991) believes the impact of market concentration on survival would change as time goes by, being positive on short-run survival but null on long-run survival.

Bogliacino and Pianta (2013) use the growth of industry sales to reflect industry demand; Sharma and Kesner (1996) also state that high industry growth means expanding demand and then new entrants would cause less threat to incumbents and suffer less retaliation from incumbents. The empirical study of Baggs (2005) shows that industry growth works as a positive factor to survival. Burke and Hanley (2009) further quantify the positive effects on survival particularly that 10 percent of industry growth would promote the survival of new venture at about 1 percent. On the other hand, Audretsch, Houweling and Thurik (2000) use average growth rates of industry sales as the proxy of the effects of industry life cycle (differentiating in product standardization and uncertainty) and believe that high growth industries contain high uncertainty, thus showing relatively low survival of new firms there.

Hypothesis 11: Industry entry rate is a negative indicator to success.

Hypothesis 12: Industry concentration is a negative indicator to success.

Hypothesis 13: Industry growth is a positive indicator to success.

\section{Data, variables and methodology}

The total samples of manufacturing and distributive sectors are selected from the Spanish firms incorporated in 2008 and 2009 in Iberian Balance sheet Analysis System (SABI) database from INFORMA D\&B and Bureau Van Dijk. The first detailed criterion for the selection is that the incorporated firms should report operating revenues in the year of age 1 . Here the year of age 1 is the year after the incorporation year — that is, 2009 and 2010 are separately the age 1 years of the firms incorporated in 2008 and 2009. There are two reasons behind. Firstly, selecting age 1 as the beginning year of study can avoid difficulties in comparing the financial status of newly incorporated firms. Because the incorporating dates of new firms are dispersed among their incorporation 
year, their financial statements usually cannot completely cover the incorporation year but just cover several months from the incorporating date to the end of that year. Secondly, a number of firms do not report their operating revenues in their incorporation year; by contrast, the proportion of firms reporting operating revenues in their age 1 year (the year after incorporation year) is much higher than that of those reporting in the incorporation year.

The numbers of firms in total samples for manufacturing and distributive sectors are separately 4382 (2327 from the 2008 cohort and 2055 from the 2009 cohort) and 12865 (6683 from the 2008 cohort and 6182 from the 2009 cohort); and, for the sake of enlarging the size of sample, the firms incorporated in 2008 and 2009 are put together, which means that incorporation year does not work as a variable in analysis. The distributions of firms in manufacturing and distributive sectors are shown in Table 1.

\begin{tabular}{|c|c|c|}
\hline Manufacturing sector & Number & Percent \\
\hline 10. Manufacture of food products & 425 & 9.70 \\
\hline 11. Manufacture of beverages & 111 & 2.53 \\
\hline 13. Manufacture of textiles & 136 & 3.10 \\
\hline 14. Manufacture of wearing apparel & 120 & 2.74 \\
\hline 15. Manufacture of leather and related products & 169 & 3.86 \\
\hline $\begin{array}{l}\text { 16. Manufacture of wood and of products of wood and cork. except furniture; } \\
\text { manufacture of articles of straw and plaiting materials }\end{array}$ & 227 & 5.18 \\
\hline 17. Manufacture of paper and paper products & 41 & 0.94 \\
\hline 18. Printing and reproduction of recorded media & 355 & 8.10 \\
\hline 19. Manufacture of coke and refined petroleum products & 4 & 0.09 \\
\hline 20. Manufacture of chemicals and chemical products & 114 & 2.60 \\
\hline 21. Manufacture of basic pharmaceutical products and pharmaceutical preparations & 16 & 0.37 \\
\hline 22. Manufacture of rubber and plastic products & 127 & 2.90 \\
\hline 23. Manufacture of other non-metallic mineral products & 189 & 4.31 \\
\hline 24. Manufacture of basic metals & 81 & 1.85 \\
\hline 25. Manufacture of fabricated metal products. except machinery and equipment & 913 & 20.84 \\
\hline 26. Manufacture of computer. electronic and optical products & 82 & 1.87 \\
\hline 27. Manufacture of electrical equipment & 85 & 1.94 \\
\hline 28. Manufacture of machinery and equipment n.e.c. & 252 & 5.75 \\
\hline 29. Manufacture of motor vehicles. trailers and semi-trailers & 41 & 0.94 \\
\hline 30. Manufacture of other transport equipment & 36 & 0.82 \\
\hline 31. Manufacture of furniture & 246 & 5.61 \\
\hline 32. Other manufacturing & 152 & 3.47 \\
\hline 33. Repair and installation of machinery and equipment & 460 & 10.50 \\
\hline Total & 4382 & 100.00 \\
\hline Distributive sector & Number & Percent \\
\hline 45. Wholesale and retail trade and repair of motor vehicles and motorcycles & 1330 & 10.34 \\
\hline 46. Wholesale trade. except of motor vehicles and motorcycles & 6362 & 49.45 \\
\hline 47. Retail trade. except of motor vehicles and motorcycles & 5173 & 40.21 \\
\hline Total & 12865 & 100.00 \\
\hline
\end{tabular}

Table 1. Distribution of firm's number and percentage in two-digit code division (according to NACE Rev. 2 from Eurostat; European Commission, 2008)

Logistic regression works here for analyzing the impacts and predictability of different factors. In particular, the variables are processed twice: in the first time, variables are put into the regression one after another and only the variables being statistically significant at the confidence level of 95 percent are allowed to go into the second time regression; in the second time, all the statistically significant variables in the last step are put into the regression together to finally identify statistical significance again at the confidence level of 95 percent, and only the finally statistically significant variables are documented. Here, for addressing the issue that the numbers of firms in success groups are larger than those in failure groups, weighting is used in the regressions.

The method classifying samples for regressing could be seen as the accumulation of traditional survival time dividing method based on time change. Traditional survival time division is to set a certain time period after the 
start of new firm and then to analyze the impacts of factors on survival of the firms that survive beyond that period and those that do not. For example, Audretsch (1994) observes the impacts of factors at different time points after the established year. Here the observation method used by Hunter and Isachenkova (2006) is also referred to (that is, one year and two years before failure work as the studying time points).

The purpose of the method used in this paper is to identify the predictability of factors in different studying years (particularly, age 1, age 2, and age 3) for different periods of time. Specifically speaking, with using the data of age 1 (as the studying year), predictability can be observed three times (immediately after the studying year, after one year, and after two years); with using the data of age 2, predictability can be observed twice (immediately after the studying year and after one year); with using the data of age 3, predictability can be observed only once (immediately after the studying year). The specific explanation of the above described six times classification and prediction would be illustrated in next section. The reason for studying till age 3 is that the whole observation period is five years after incorporation and the data in the years of age 4 and 5 can only be used to identify whether showing operating revenues in two consecutive years. Here noteworthy is that, when exploring the predictability of age 2 or age 3 , it means that the firms survive at least till that age.

Table 2 and 3 describe the detailed information about the factors and variables chosen from a variety of literature: seven from the research of Murphy et al. (1996) — success or failure, size, market share, profit, leverage, liquidity, and efficiency; bank debt from the research of Saridakis et al. (2008); trade credit from the studies of Martínez-Sola et al. (2014) and Kestens, Van Cauwenberge and Bauwhede (2012); industrial variables from the research of Geroski et al. (2010), López-García and Puente (2006), and Baggs (2005). Here size and market share are treated asaccounting-based factors in that they are calculated on the ground of the data in financial statements; and, except for corporate venturing (representing whether an incorporated firm belongs to a group; used in the study of Bridges and Guariglia (2008)), all the factors and variables could change with time.

For addressing the problem of collinearity, changes are done on some variables. Mathematical reciprocals are calculated on indebtedness and general liquidity. Similar to the classifying method used by Westhead and Storey (1997), profitability is subdivided into two types (gaining profits or not), based on the fact that a proportion of firms suffer losses in the samples. This type of classifying is also suitable for bank debt (bank loans), like in the study of Reid and Smith (2000). As for the three industrial variables, the measures here of entry rate and industry growth are generally in accordance with past literature; while the measuring method of López-García and Puente (2006) for concentration (the proportion of operating revenues of the top 10 percent firms to that of the whole industry) is adopted here, considering the large number of firms in distributive sector and the difficulty for calculating Herfindahl concentration index being used in the research of, for instance, Delmar et al. (2013).

\begin{tabular}{|l|l|l|}
\hline Dependent variable & Definition & Measure \\
\hline Success or failure & $\begin{array}{l}\text { Whether or not showing the failure event: } \\
\text { two consecutive years without reporting } \\
\text { operating revenues }\end{array}$ & $\begin{array}{l}\text { It equals 1 if not showing the defined failure event } \\
\text { during the observed period, meaning success; equals } \\
\text { 0 if showing the defined failure event during the } \\
\text { observed period, meaning failure. }\end{array}$ \\
\hline
\end{tabular}

Table 2. Definition of dependent variable 


\begin{tabular}{|c|c|c|c|}
\hline Factors & Independent variables & Definitions & Measures in regression \\
\hline Firm size & Total assets & Total assets in thousands of Euros & $\begin{array}{l}\text { Natural logarithm of one plus total } \\
\text { assets: Ln (1+total assets in } \\
\text { thousands of Euros) }\end{array}$ \\
\hline Market share & $\begin{array}{l}\text { Proportion of firm's } \\
\text { operating revenues to } \\
\text { the total amount of } \\
\text { operating revenues in } \\
\text { the industry where that } \\
\text { firm is }\end{array}$ & $\begin{array}{l}\text { Firm's operating revenues/The total } \\
\text { amount of operating revenues in the } \\
\text { industry where that firm is }\end{array}$ & $\begin{array}{l}\text { Firm's operating revenues/The total } \\
\text { amount of operating revenues in the } \\
\text { industry where that firm is }\end{array}$ \\
\hline $\begin{array}{l}\text { Profitability (or } \\
\text { profit) }\end{array}$ & Economic profitability & Profits before tax/Total assets & $\begin{array}{l}\text { Profitability, equals } 1 \text { if firm's } \\
\text { economic profitability is positive } \\
\text { figure; equals } 0 \text { if firm's economic } \\
\text { profitability is zero or negative figure. }\end{array}$ \\
\hline $\begin{array}{l}\text { Solvency (or } \\
\text { leverage) }\end{array}$ & Indebtedness & $\begin{array}{l}\text { (Total shareholders funds and } \\
\text { liabilities-Shareholders } \\
\text { equity)/Total shareholders funds and } \\
\text { liabilities }\end{array}$ & $\begin{array}{l}\text { Reciprocal of indebtedness: } \\
1 \text { /indebtedness }\end{array}$ \\
\hline Liquidity & General liquidity & Current assets/Current liabilities & $\begin{array}{l}\text { Reciprocal of general liquidity: } \\
1 \text { /general liquidity }\end{array}$ \\
\hline Efficiency & Asset rotation & Sales/Total assets & Sales/Total assets \\
\hline Bank credit & Bank loans & $\begin{array}{l}\text { Whether showing positive bank loans } \\
\text { in balance sheet (liabilities) }\end{array}$ & $\begin{array}{l}\text { bank loans, equal } 1 \text { if positive bank } \\
\text { loans are shown in firm's balance } \\
\text { sheet (liabilities); equals } 0 \text { if positive } \\
\text { bank loans are not shown in firm's } \\
\text { balance sheet (liabilities) }\end{array}$ \\
\hline \multirow[t]{2}{*}{ Trade credit } & $\begin{array}{l}\text { Proportion of accounts } \\
\text { receivable to total assets }\end{array}$ & Accounts receivable/Total assets & Accounts receivable/Total assets \\
\hline & $\begin{array}{l}\text { Proportion of accounts } \\
\text { payable to total liabilities }\end{array}$ & Accounts payable/Total liabilities & Accounts payable/Total liabilities \\
\hline $\begin{array}{l}\text { Corporate } \\
\text { venturing }\end{array}$ & Corporate venturing & $\begin{array}{l}\text { Number of companies in corporate } \\
\text { group }\end{array}$ & $\begin{array}{l}\text { Corporate venturing, equals } 1 \text { if the } \\
\text { number of companies in corporate } \\
\text { group is more than zero; equals } 0 \text { if } \\
\text { the number of companies in } \\
\text { corporate group is zero. }\end{array}$ \\
\hline \multirow[t]{3}{*}{$\begin{array}{l}\text { Industrial factors } \\
\text { (identified in } \\
\text { two-digit code } \\
\text { division in } \\
\text { Table 1) }\end{array}$} & Entry rate & $\begin{array}{l}\text { Proportion of the number of } \\
\text { incorporated firms within a year in a } \\
\text { selected industry to the number of } \\
\text { the firms reporting total assets in that } \\
\text { industry in the same year }\end{array}$ & $\begin{array}{l}\text { The number of incorporated firms } \\
\text { within a year in a selected } \\
\text { industry/The number of the firms } \\
\text { reporting total assets in that industry } \\
\text { in the same year }\end{array}$ \\
\hline & Concentration rate & $\begin{array}{l}\text { Proportion of the total amount of } \\
\text { operating revenues of the top } 10 \\
\text { percent firms in a selected industry in } \\
\text { a year to the total amount of } \\
\text { operating revenues in that industry in } \\
\text { the same year }\end{array}$ & $\begin{array}{l}\text { The total amount of operating } \\
\text { revenues of the top } 10 \text { percent firms } \\
\text { in a selected industry in a year/The } \\
\text { total amount of operating revenues } \\
\text { in that industry in the same year }\end{array}$ \\
\hline & Industry growth rate & $\begin{array}{l}\text { Rate of the difference between } \\
\text { operating revenues in a selected } \\
\text { industry in a year and the operating } \\
\text { revenues in that industry one year } \\
\text { before to the operating revenues in } \\
\text { that industry one year before }\end{array}$ & $\begin{array}{l}\text { (Operating revenues in a selected } \\
\text { industry in a year — the operating } \\
\text { revenues in that industry one year } \\
\text { before)/ The operating revenues in } \\
\text { that industry one year before }\end{array}$ \\
\hline
\end{tabular}

Table 3. Definitions of independent variables 


\section{Regression results}

The detailed results of the regressions in manufacturing and distributive sectors are shown separately in Table 4 and Table 5 (where only the variables that are statistically significant at the confidence level of 95 percent are recorded); and the comparisons of the hypotheses and findings are described in Table 6. Particularly in each sector, there are six classifications representing different studying years and different observation periods, which would be explained in the following paragraph and Figure 1.

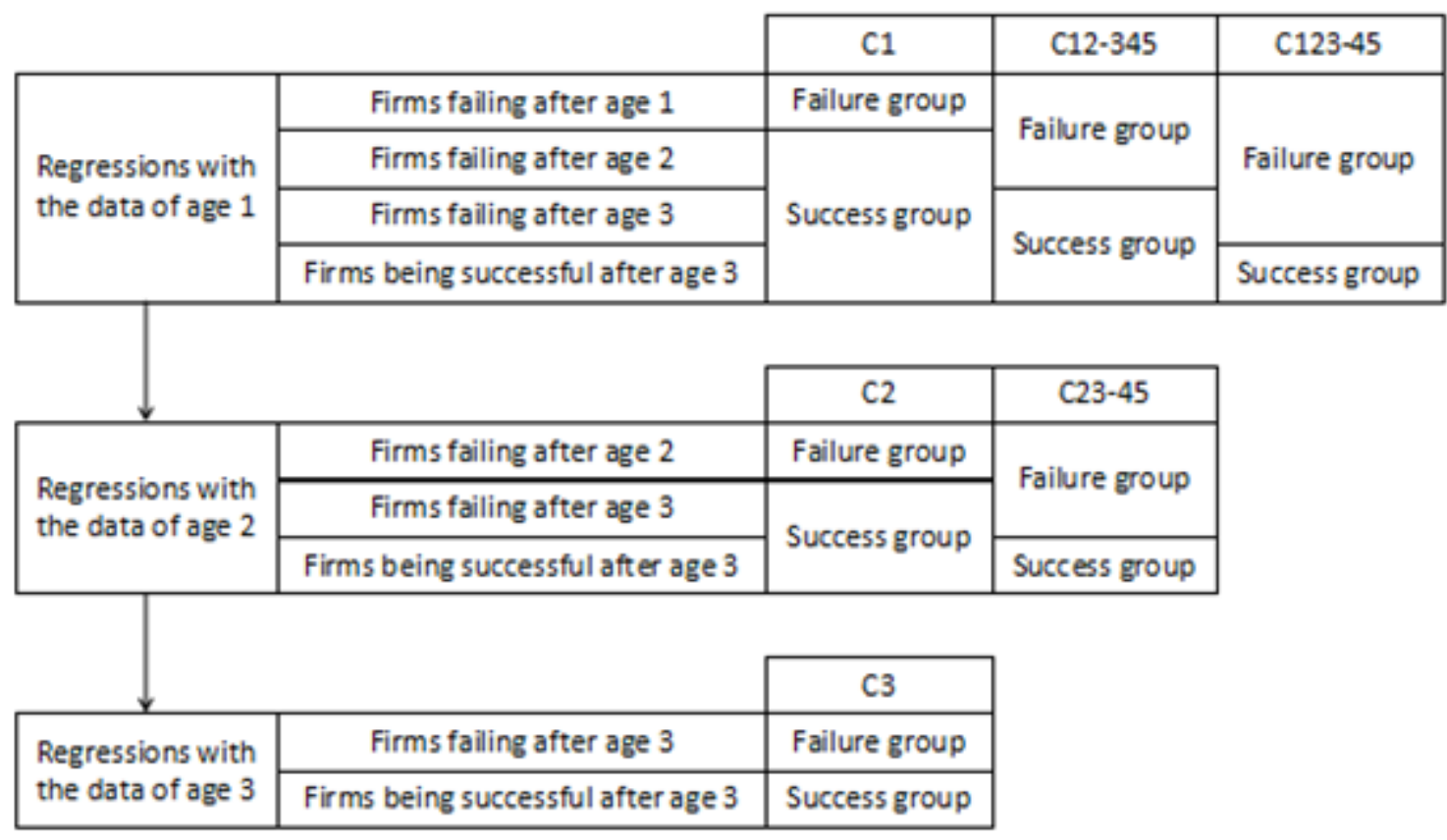

Figure 1. Classifications for respectively regressing

In the regressions with using the data of age 1 , the firms in the year of age 1 are initially subdivided into four categories: those failing after age 1, those failing after age 2, those failing after age 3 , and those being successful after age 3. Then, the first classification (C1) identifies only the firms failing after age 1 as failure group and the residual three categories together as success group; the second classification (C12-345) identifies the firms failing after age 1 and those failing after age 2 as failure group and the other residual two categories together as success group; the third classification (C123-45) identifies the firms failing after age 1, failing after age 2, and failing after age 3 as failure group and the other residual one category as success group. In the regressions with using the data of age 2 and age 3 , the classifications are similar to those of age 1.

Generally speaking, there are more variables showing statistical significance in distributive sector than in manufacturing sector. In particular, entry rate and concentration are never statistically significant in manufacturing sector but frequently show significance in distributive sector (separately with negative and positive relationships to success). Trade credit variables also only show statistical significance in distributive sector (with negative relationships of accounts receivable and positive relationship of accounts payable to success). Besides, though positive effects of general liquidity and indebtedness are observed, in distributive sector the appearing frequency of statistical significance of general liquidity is much higher than that of indebtedness.

Despite the previously listed differences, similarities in the two sectors can still be summarized as follows. The first undoubted common result is that total assets and profitability show statistically significant and positive effects on success in every regression in both manufacturing and distributive sectors while market share never shows significance even once. Secondly, positive effects of corporate venturing as well as negative effects of the growth rate of industrial operating revenues are commonly (or in majority) observed in both two sectors. 
Thirdly, so limited are the impacts of asset rotation and bank loans that statistically significant result is recorded only once each (asset rotation showing negative relationship to success in manufacturing sector; bank loans showing positive relationship to success in distributive sector).

Analyzing the value of coefficient (B) is helpful to identify not only the impacts of factors per se but also the changes of the impacts, as increase (or decrease) in the absolute value of coefficient means increase (or decrease) in its impacts. In both manufacturing and distributive sectors, the values of coefficients of the natural logarithm of total assets and corporate venturing are positive and generally keep stable, so this signifies relatively steady effects of these two factors; by contrast, increasing trends are observed from $\mathrm{C} 1$ to $\mathrm{C} 3$ in the value of profitability's coefficient, meaning increment of the impacts of profitability from age 1 to age 3 . Increasing trend also appears in the absolute value of the coefficient of the growth rate of industrial operating revenues, although along with the change of its sign from being negative to being positive. On the other hand, in distributive sector, instability is shown in the absolute values of the coefficients of the reciprocal of general liquidity, entry rate and concentration, stable signs notwithstanding.

\begin{tabular}{|c|c|c|c|c|c|c|c|c|c|c|c|c|}
\hline \multirow[t]{2}{*}{$\begin{array}{l}\text { Manufacturing } \\
\text { sector }\end{array}$} & \multicolumn{2}{|c|}{$\begin{array}{l}\text { C1 (predicted } \\
60.7 \% \text { ) }\end{array}$} & \multicolumn{2}{|c|}{$\begin{array}{l}\mathrm{C} 12-345 \\
(58.7 \%)\end{array}$} & \multicolumn{2}{|c|}{$\begin{array}{l}\text { C123-45 } \\
(57.4 \%)\end{array}$} & \multicolumn{2}{|c|}{ C2 (61.2 \%) } & \multicolumn{2}{|c|}{$\begin{array}{l}\mathrm{C} 23-45 \\
(60.1 \%)\end{array}$} & \multicolumn{2}{|c|}{ C3 $(62.6 \%)$} \\
\hline & B & Sig. & B & Sig. & B & Sig. & B & Sig. & B & Sig. & B & Sig. \\
\hline Ln Total assets & 0.158 & 0.000 & 0.144 & 0.000 & 0.130 & 0.000 & 0.141 & 0.000 & 0.131 & 0.000 & 0.172 & 0.000 \\
\hline \multicolumn{13}{|l|}{$\begin{array}{l}\text { Firm's operating } \\
\text { revenues to that of } \\
\text { the whole industry }\end{array}$} \\
\hline Profitability & 0.653 & 0.000 & 0.545 & 0.000 & 0.504 & 0.000 & 0.730 & 0.000 & 0.627 & 0.000 & 0.947 & 0.000 \\
\hline $\begin{array}{l}\text { Reciprocal of } \\
\text { indebtedness }\end{array}$ & & & & & & & -0.008 & 0.003 & -0.007 & 0.025 & & \\
\hline \multicolumn{13}{|l|}{ Bank loans } \\
\hline \multicolumn{13}{|l|}{$\begin{array}{l}\text { Accounts } \\
\text { receivables to total } \\
\text { assets }\end{array}$} \\
\hline \multicolumn{13}{|l|}{$\begin{array}{l}\text { Accounts payable } \\
\text { to total liabilities }\end{array}$} \\
\hline $\begin{array}{l}\text { Reciprocal of } \\
\text { general liquidity }\end{array}$ & -0.060 & 0.000 & & & & & -0.055 & 0.000 & -0.031 & 0.001 & & \\
\hline Asset rotation & & & & & & & & & & & -0.022 & 0.010 \\
\hline $\begin{array}{l}\text { Corporate } \\
\text { venturing }\end{array}$ & & & 0.176 & 0.001 & 0.168 & 0.003 & 0.146 & 0.008 & 0.152 & 0.009 & & \\
\hline \multicolumn{13}{|l|}{ Entry rate } \\
\hline \multicolumn{13}{|l|}{ Concentration } \\
\hline $\begin{array}{l}\text { Rate of growth of } \\
\text { industrial } \\
\text { operating revenues }\end{array}$ & -0.686 & 0.000 & -0.645 & 0.001 & -0.675 & 0.001 & -1.377 & 0.000 & & & 1.774 & 0.000 \\
\hline
\end{tabular}

Table 4. Regression results in manufacturing sector $(B=$ coefficient; Sig. $=$ statistical significance $)$ 


\begin{tabular}{|c|c|c|c|c|c|c|c|c|c|c|c|c|}
\hline \multirow[t]{2}{*}{ Distributive sector } & \multicolumn{2}{|c|}{$\begin{array}{c}\text { C1 (predicted } \\
60.5 \%)\end{array}$} & \multicolumn{2}{|c|}{$\begin{array}{l}\text { C12-345 } \\
(59.9 \%)\end{array}$} & \multicolumn{2}{|c|}{$\begin{array}{l}\text { C123-45 } \\
(60.2 \%)\end{array}$} & \multicolumn{2}{|c|}{ C2 $(63.3 \%)$} & \multicolumn{2}{|c|}{ C23-45 (63.1\%) } & \multicolumn{2}{|c|}{ C3 $(65.0 \%)$} \\
\hline & B & Sig. & B & Sig. & B & Sig. & B & Sig. & B & Sig. & B & Sig. \\
\hline Ln Total assets & 0.238 & 0.000 & 0.208 & 0.000 & 0.215 & 0.000 & 0.213 & 0.000 & 0.219 & 0.000 & 0.261 & 0.000 \\
\hline \multicolumn{13}{|l|}{$\begin{array}{l}\text { Firm's operating } \\
\text { revenues to that of } \\
\text { the whole industry }\end{array}$} \\
\hline Profitability & 0.642 & 0.000 & 0.622 & 0.000 & 0.606 & 0.000 & 0.849 & 0.000 & 0.853 & 0.000 & 1.088 & 0.000 \\
\hline $\begin{array}{l}\text { Reciprocal of } \\
\text { indebtedness }\end{array}$ & & & & & & & & & & & -0.002 & 0.005 \\
\hline Bank loans & & & & & & & 0.073 & 0.021 & & & & \\
\hline $\begin{array}{l}\text { Accounts } \\
\text { receivables to total } \\
\text { assets }\end{array}$ & -0.385 & 0.000 & & & & & & & -0.166 & 0.007 & & \\
\hline $\begin{array}{l}\text { Accounts payable to } \\
\text { total liabilities }\end{array}$ & & & & & 0.101 & 0.037 & & & & & & \\
\hline $\begin{array}{l}\text { Reciprocal of } \\
\text { general liquidity }\end{array}$ & -0.013 & 0.000 & -0.016 & 0.000 & -0.014 & 0.003 & -0.025 & 0.000 & -0.010 & 0.001 & -0.007 & 0.001 \\
\hline \multicolumn{13}{|l|}{ Assetrotation } \\
\hline Corporateventuring & 0.107 & 0.000 & 0.204 & 0.000 & 0.268 & 0.000 & 0.214 & 0.000 & 0.268 & 0.000 & 0.198 & 0.000 \\
\hline Entryrate & -12.245 & 0.000 & -11.429 & 0.000 & -11.845 & 0.000 & -28.265 & 0.000 & & & -13.563 & 0.000 \\
\hline Concentration & & & 1.939 & 0.000 & 1.751 & 0.002 & 5.087 & 0.000 & & & 2.775 & 0.000 \\
\hline $\begin{array}{l}\text { Rate of growth of } \\
\text { industrial operating } \\
\text { revenues }\end{array}$ & & & -0.499 & 0.014 & -0.729 & 0.001 & 4.194 & 0.000 & & & & \\
\hline
\end{tabular}

Table 5. Regression results in distributive sector $(B=$ coefficient; Sig.=statistical significance)

\begin{tabular}{|l|l|l|}
\hline Hypotheses & Supported or not by findings & Effects found \\
\hline $\begin{array}{l}\text { Hypothesis 1: Firm size is a positive } \\
\text { indicator. }\end{array}$ & Strongly supported & Positive and strong \\
\hline $\begin{array}{l}\text { Hypothesis 2: Market share is a } \\
\text { positive indicator. }\end{array}$ & Not supported & No significance \\
\hline $\begin{array}{l}\text { Hypothesis 3: Profitability is a } \\
\text { positive indicator. }\end{array}$ & Strongly supported & Positive and strong \\
\hline $\begin{array}{l}\text { Hypothesis 4: Indebtedness is a } \\
\text { negative indicator. }\end{array}$ & Not supported & Positive but weak \\
\hline $\begin{array}{l}\text { Hypothesis 5: Bank debt is a positive } \\
\text { indicator. }\end{array}$ & Weakly supported & Positive but weak \\
\hline $\begin{array}{l}\text { Hypothesis 6: Accounts receivable is } \\
\text { a negative indicator. }\end{array}$ & Weakly supported & Negative but weak \\
\hline $\begin{array}{l}\text { Hypothesis 7: Accounts payable is a } \\
\text { positive indicator. }\end{array}$ & Weakly supported & Positive but weak \\
\hline $\begin{array}{l}\text { Hypothesis 8: General liquidity is a } \\
\text { positive indicator. }\end{array}$ & $\begin{array}{l}\text { Weakly supported in manufacturing; strongly } \\
\text { supported in distributive sector }\end{array}$ & Positive \\
\hline $\begin{array}{l}\text { Hypothesis 9: Asset rotation is a } \\
\text { positive indicator. }\end{array}$ & Not supported & Negative but weak \\
\hline $\begin{array}{l}\text { Hypothesis 10: Corporate venturing } \\
\text { is a positive indicator. }\end{array}$ & Strongly supported & Positive and strong \\
\hline $\begin{array}{l}\text { Hypothesis 11: Industry entry rate is } \\
\text { a negative indicator. }\end{array}$ & Strongly supported only in distributive sector & Negative and strong \\
\hline $\begin{array}{l}\text { Hypothesis 12: Industry } \\
\text { concentration is a negative indicator. }\end{array}$ & Not supported \\
\hline $\begin{array}{l}\text { Hypothesis 13: Industry growth is a } \\
\text { positive indicator. }\end{array}$ & Dichotomous & $\begin{array}{l}\text { Positive and strong only in } \\
\text { distributive sector }\end{array}$ \\
\hline
\end{tabular}

Table 6. Comparisons of the hypotheses and findings 


\section{Conclusion, implication and future research}

Before summarizing the predictability and impacts, a special point of conclusion for the variables frequently showing statistical significance can be extracted from the previous analysis of the values of coefficients. That is, when studying the predictability from age 1 to age 3 , the impacts of firm size and corporate venturing change only to a little extent; even for the factors and variables that show different impacts across ages (such as, profitability, entry rate, concentration, and the growth rate of industrial operating revenues), their impacts in the same age tend to be relatively stable.

Generally speaking, it is easy to conclude the existence of difference in factors' predictability on success when comparing manufacturing and distributive sectors. Nevertheless, some factors still have overwhelming effects on the success of newly incorporated firms. Firm size and profitability are the most strongly predictable factors as the proxy variables of these two show statistically significant and positive effects on success in all the regressions. This corresponds to the assumptions and the record of most literature, including the views of Audretsch (1991) and Audretsch and Mahmood (1995) about inherent size disadvantage and the study of Delmar et al. (2013) on profitability.

Corporate venturing follows the above two as the second strong positive factor, which is similar to the findings of Bridges and Guariglia (2008). So this result illustrates the usefulness of obtaining experience from the established parent companies, as is expected by Audretsch and Mahmood (1995). Here the predictability of corporate venturing seems to be stronger in distributive sector, because of showing statistical significance in all the regressions in distributive sector (rather than manufacturing sector).

Completely different to those strong factors, market share does not show statistically significance at all when controlling other variables. This does not correspond to the expectation that market share should have similar effects to size by virtue of the expected correlation between market share and firm size. A possible explanation may be that the market shares of entrants are too small to cause effects, which is to some extent linked to the view of Audretsch, Santarelli and Vivarelli (1999) saying that the gross market share of entrants usually is not as high as the rate of new firm formation.

Albeit not always showing statistical significance, the effects of liquidity and solvency factors are stable and positive, since all the reciprocals of general liquidity and indebtedness show negative signs in the regressions in which they are statistically significant. Furthermore, the frequency of statistical significance of the reciprocal of general liquidity is quite high in distributive sector, so it is reasonable to ascertain that the predictability of liquidity in distributive sector is strong. Positive effect of liquidity is also supported by Bunn and Redwood (2003). In terms of the positive effect of indebtedness, though not corresponding to the assumption, it is close to the empirical findings of Nunes and Serrasqueiro (2012).

The low frequency of statistical significance in bank loans, accounts receivable, and accounts payable means that credit factors (including both bank credit and trade credit) are weak indicators on the success of newly incorporated firms; however, the empirical results in distributive sector (positive effects of bank loans and accounts payable as well as negative effect of accounts receivable) do not go beyond the assumptions. Here positive effect of accounts payable and negative effect of accounts receivable indicate generally positive effect of trade credit, for the reason that holding more accounts payable and less accounts receivable represents increment in trade credit. Therefore it is possible to explain the above results that: the strength of the predictability of credit factors may change from sector to sector; and in the sectors where showing statistical significance (like distributive sector here), some weight should be given to both bank credit and trade credit, because they are the two major sources of debt-financing for start-ups (Huyghebaert, Van de Gucht \& Van Hulle, 2007). The impact of asset rotation as the proxy of efficiency is questioned too due to its low frequency of statistical significance, which is similar to the research results of Charitou et al. (2004) challenging its significance as well.

With regard to the three industrial variables, the growth of industrial operating revenues shows statistical significance most but its impact on success is not constant (mostly being negative but occasionally being positive). Though the result of the negative impact is contrary to the theoretical assumption and some empirical 
results, like of Baggs (2005), similar results can still be found frompast research, for example the research of Audretsch et al. (2000) where the negative effect of industry growth is kept till age 8. So the statement of Audretsch et al. (2000) that uncertainty is entwined with industry's high growth could be employed to explain the negative effect; however, this effect seems to be maintained at early ages, because positive effect emerges later.

Entry rate shows statistical significance only in distributive sector; its effect on success is consistently negative and this negative effect is within the setting of competition theory of Fritsch et al. (2006). The effect of concentration on success keeps on being positive and statistically significant too only in distributive sector. This is different to many empirical studies; however, from another angle it may implicitly support the views of Baldwin and Rafiquzzaman (1995) pointing out that entrants could not threaten the existing firms immediately due to smallness and Cincera and Galgau (2005) showing that the time for a new firm to be competitive with incumbents should be five to ten years.

As for practical implications, the findings of this paper can help to identify the predictability of different factors on success: for example, firm size and profitability are suitable for predicting success in any of the first three years. In addition to that, the differences observed in predictability between manufacturing and distributive sectors mean that it is necessary to research on different industrial sectors to catch the similarities and differences of the impacts of same factor in different industries.

Just as mentioned at the beginning of this paper, the definition of success could be different in different studies, so future research would consider to adopt multiple classifying method to measure success and in that way it would be possible to test the predictability of factors on success under different criteria. Besides, it is also suggested to lengthen the observation period (if possible) for the sake of analyzing factors' long-term impacts and predictability in future research.

\section{Declaration of Conflicting Interests}

The authors declared no potential conflicts of interest with respect to the research, authorship, and/or publication of this article.

\section{Funding}

The authors received no financial support for the research, authorship, and/or publication of this article.

\section{References}

Agarwal, R., \& Audretsch, D.B. (1999). The two views of small firms in industry dynamics: A reconciliation. Economics Letters, 62(2), 245-251. https://doi.org/10.1016/S0165-1765(98)00234-1

Aldrich, H.E., \& Auster, E.R. (1986). Even dwarfs started small: Liabilities of age and size and their strategic implications. Research in Organizational Behavior: An Annual Series of Analytical Essays and Critical Reviews, 8, 165-198.

Altman, E.I. (1968). Financial ratios, discriminant analysis and the prediction of corporate bankruptcy. The Journal of Finance, 23(4), 589-609. https://doi.org/10.1111/j.1540-6261.1968.tb00843.x

Altman, E.I., Haldeman, R.G., \& Narayanan, P. (1977). Zeta analysis: A new model to identify bankruptcy risk of corporations. Journal of Banking \& Finance, 1(1),29-54. https://doi.org/10.1016/0378-4266(77)90017-6

Amason, A.C., Shrader, R.C., \& Tompson, G.H. (2006). Newness and novelty: Relating top management team composition to new venture performance. Journal of Business Venturing, 21(1), 125-148.

https://doi.org/10.1016/j.jbusvent.2005.04.008

Ardalan, K. (2017). Capital structure theory: Reconsidered. Research in International Business and Finance, 39, 696-710. https://doi.org/10.1016/j.ribaf.2015.11.010

Åstebro, T., \& Bernhardt, I. (2003). Start-up financing, owner characteristics, and survival. Journal of Economics and Business, 55(4), 303-319. https://doi.org/10.1016/S0148-6195(03)00029-8 
Audretsch, D.B. (1991). New-firm survival and the technological regime. The Review of Economics and Statistics, 73(3), 441-450. https://doi.org/10.2307/2109568

Audretsch, D.B. (1994). Business survival and the decision to exit. International Journal of the Economics of Business, 1(1), 125-137. https://doi.org/10.1080/758540503

Audretsch, D.B. (1995). The propensity to exit and innovation. Review of Industrial Organization, 10(5), 589-605. https://doi.org/10.1007/BF01026884

Audretsch, D.B., Houweling, P., \& Thurik, A.R. (2000). Firm survival in the Netherlands. Review of Industrial Organization, 16(1), 1-11. https://doi.org/10.1023/A:1007824501527

Audretsch, D.B., \& Mahmood, T. (1995). New firm survival: New results using a hazard function. The Review of Economics and Statistics, 77(1), 97-103. https://doi.org/10.2307/2109995

Audretsch, D.B., Santarelli, E. \& Vivarelli, M. (1999). Start-up size and industrial dynamics: Some evidence from Italian manufacturing. International Journal of Industrial Organization, 17(7), 965-983.

https://doi.org/10.1016/S0167-7187(98)00002-2

Baggs, J. (2005). Firm survival and exit in response to trade liberalization. The Canadian Journal of Economics / Revue canadienned'Economique, 38(4), 1364-1383. https://doi.org/10.1111/j.0008-4085.2005.00328.x

Baldwin, J.R., \& Rafiquzzaman, M. (1995). Selection versus evolutionary adaptation: Learning and post-entry performance. International Journal of Industrial Organization, 13(4), 501-522. https://doi.org/10.1016/0167$7187(95) 00502-1$

Bartelsman, E., Scarpetta, S. \& Schivardi, F. (2005). Comparative analysis of firm demographics and survival: Evidence from micro-level sources in OECD countries. Industrial and Corporate Change, 14(3), 365-391. https://doi.org/10.1093/icc/dth057

Bastié, F., Cieply, S., \& Cussy, P. (2011). The survival of new firms: Do bank loans at birth matter?. Economics Working Paper Archive (University of Rennes 1 \& University of Caen) from Center for Research in Economics and Management (CREM), University of Rennes 1, University of Caen and CNRS. Retrieved from: http://crem.univ-rennes1.fr/wp/2011/201110.pdf

Bierwerth, M., Schwens, C., Isidor, R., \& Kabst, R. (2015). Corporate entrepreneurship and performance: A meta-analysis. Small Business Economics, 45(2), 255-278. https://doi.org/10.1007/s11187-015-9629-1

Bogliacino, F., \& Pianta, M. (2013). Innovation and demand in industry dynamics: R\&D, new products and profits. In A. Pyka \& E.S. Andersen (Eds.), Long Term Economic Development (part of the series Economic Complexity and Evolution) (pp. 95-112). Berlin Heidelberg: Springer-Verlag. https://doi.org/10.1007/978-3642-35125-9_5

Bourantas, D., \& Mandes, Y. (1987). Does market share lead to profitability?. Long Range Planning, 20(5), 102-108. https://doi.org/10.1016/0024-6301(87)90097-5

Bridges, S., \& Guariglia, A. (2008). Financial constraints, global engagement, and firm survival in the United Kingdom: Evidence from micro data. Scottish Journal of Political Economy, 55(4),444-464. https://doi.org/10.1111/j.1467-9485.2008.00461.x

Brüderl, J., \& Preisendörfer, P. (1998). Network support and the success of newly founded businesses. Small Business Economics, 10(3), 213-225. https://doi.org/10.1023/A:1007997102930

Brüderl, J., Preisendörfer, P., \& Ziegler, R. (1992). Survival chances of newly founded business organizations. American Sociological Review, 57(2), 227-242.

Bunn, P., \& Redwood, V. (2003). Company accounts based modelling of business failures and the implications for financial stability. Bank of England, Working Paper No. 210. Retrieved from:

http://www.bankofengland.co.uk/archive/Documents/historicpubs/workingpapers/2003/wp210.pdf 
Burke, A., \& Hanley, A. (2009). Market concentration and business survival in static v dynamic industries. Kiel Working Papers from Kiel Institute for the World Economy, No. 1517. Retrieved from: https://www.ifw-members.ifwkiel.de/publications/market-concentration-and-business-survival-in-static-v-dynamic-industries-3/kwp-1517.pdf

Charitou, A., Neophytou, E., \& Charalambous, C. (2004). Predicting corporate failure: Empirical evidence for the UK. European Accounting Review, 13(3), 465-497. https://doi.org/10.1080/0963818042000216811

Chrisman, J.J., Bauerschmidt, A., \& Hofer, C.W. (1998). The determinants of new venture performance: An extended model. Entrepreneurship Theory and Practice, 23(1), 5-29. https://doi.org/10.1177/104225879802300101

Cincera, M., \& Galgau, O. (2005). Impact of market entry and exit on EU productivity and growth performance. No. 222 , European Economy - Economic Papers 2008 - 2015 from Directorate General Economic and Financial Affairs (DG ECFIN), European Commission. Retrieved from: http://ec.europa.eu/economy finance/publications/pages/publication712 en.pdf

Delmar, F., McKelvie, A., \& Wennberg, K. (2013). Untangling the relationships among growth, profitability and survival in new firms. Technovation, 33(8-9), 276-291. https://doi.org/10.1016/j.technovation.2013.02.003

Disney, R., Haskel, J., \& Heden, Y. (2003). Entry, exit and establishment survival in UK manufacturing. The Journal of Industrial Economics, 51(1), 91-112. https://doi.org/10.1111/1467-6451.00193

Doran, J., McCarthy, N., \& O’Connor, M. (2016). Entrepreneurship and employment growth across European regions. Regional Studies, Regional Science, 3(1), 121-128. https://doi.org/10.1080/21681376.2015.1135406

Ericson, R., \& Pakes, A. (1995). Markov-perfect industry dynamics: A framework for empirical work. The Review of Economic Studies, 62(1), 53-82. https://doi.org/10.2307/2297841

Eurostat (European Commission) (2008). NACE Rev. 2-Statistical classification of economic activities in the European Community. Luxembourg: office for official publications of the European Communities. Retrieved from: http://ec.europa.eu/eurostat/documents/3859598/5902521/KS-RA-07-015-EN.PDF

Ferrando, A., \& Mulier, K. (2013). Do firms use the trade credit channel to manage growth?. Journal of Banking and Finance, 37(8), 3035-3046. https:// doi.org/10.1016/j.jbankfin.2013.02.013

Fotopoulos, G., \& Louri, H. (2000). Determinants of hazard confronting new entry: Does financial structure matter?. Review of Industrial Organization, 17(3), 285-300. https://doi.org/10.1023/A:1007862922531

Fraering, J.M., \& Minor, M.S. (1994). The industry-specific basis of the market share-profitability relationship. Journal of Consumer Marketing, 11(1), 27-37. https://doi.org/10.1108/07363769410053673

Fritsch, M., Brixy, U., \& Falck, O. (2006). The effect of industry, region, and time on new business survival - a multi-dimensional analysis. Review of Industrial Organization, 28(3), 285-306. https://doi.org/10.1007/s11151-0060018-4

Gale, B.T. (1972). Market share and rate of return. The Review of Economics and Statistics, 54(4), 412-423. https://doi.org/10.2307/1924568

García-Teruel, P.J., \& Martínez-Solano, P. (2010). Determinants of trade credit: A comparative study of European SMEs. International Small Business Journal, 28(3), 215-233. https://doi.org/10.1177/0266242609360603

Geroski, P.A. (1995). What do we know about entry?. International Journal of Industrial Organization, 13(4), 421-440. https://doi.org/10.1016/0167-7187(95)00498-X

Geroski, P.A., Mata, J., \& Portugal, P. (2010). Founding conditions and the survival of new firms. Strategic Management Journal, 31(5), 510-529.

Görg, H., \& Strobl, E. (2003). Multinational companies, technology spillovers and plant survival. The Scandinavian Journal of Economics, 105(4), 581-595. https://doi.org/10.1111/j.0347-0520.2003.t01-1-00003.x

Harris, M., \& Raviv, A. (1991). The theory of capital structure. The Journal of Finance, 46(1), $297-355$. https://doi.org/10.1111/j.1540-6261.1991.tb03753.x 
Hill, S.A., \& Birkinshaw, J. (2008). Strategy-organization configurations in corporate venture units: Impact on performance and survival. Journal of Business Venturing, 23(4), 423-444.

https://doi.org/10.1016/j.jbusvent.2007.04.001

Hillegeist, S.A., Keating, E.K., Cram, D.P., \& Lundstedt, K.G. (2004). Assessing the probability of bankruptcy. Review of Accounting Studies, 9(1), 5-34. https://doi.org/10.1023/B:RAST.0000013627.90884.b7

Hunter, J., \& Isachenkova, N. (2006). Aggregate economy risk and company failure: An examination of UK quoted firms in the early 1990s. Journal of Policy Modeling, 28(8), 911-919.

https://doi.org/10.1016/j.jpolmod.2006.04.014

Huyghebaert, N. (2006). On the determinants and dynamics of trade credit use: Empirical evidence from business start-ups. Journal of Business Finance \& Accounting, 33(1-2), 305-328. https://doi.org/10.1111/j.14685957.2006.001364.x

Huyghebaert, N., \& Van de Gucht, L.M. (2007). The determinants of financial structure: New insights from business start-ups. European Financial Management, 13(1), 101-133. https://doi.org/10.1111/j.1468036X.2006.00287.x

Huyghebaert, N., Van de Gucht, L., \& Van Hulle, C. (2007). The choice between bank debt and trace credit in business start-ups. Small Business Economics, 29(4), 435-452. https://doi.org/10.1007/s11187-006-9005-2

Ilmakunnas, P., \& Topi, J. (1999). Microeconomic and macroeconomic influences on entry and exit of firms. Review of Industrial Organization, 15(3), 283-301. https://doi.org/10.1023/A:1007786719982

Jensen, M.C., \& Meckling, W.H. (1976). Theory of the firm: Managerial behavior, agency costs and ownership structure. Journal of Financial Economics, 3(4), 305-360. https://doi.org/10.1016/0304-405X(76)90026-X

Jovanovic, B. (1982). Selection and the evolution of industry. Econometrica, 50(3), 649-670. https://doi.org/10.2307/1912606

Kestens, K., Van Cauwenberge, P., \& Bauwhede, H.V. (2012). Trade credit and company performance during the 2008 financial crisis. Accounting \& Finance, 52(4), 1125-1151. https://doi.org/10.1111/j.1467-629X.2011.00452.x

Kraaijenbrink, J., Spender, J.-C., \& Groen, A.J. (2010). The resource-based view: A review and assessment of its critiques. Journal of Management, 36(1), 349-372. https://doi.org/10.1177/0149206309350775

Laitinen, E.K. (1992). Prediction of failure of a newly founded firm. Journal of Business Venturing, 7(4), 323-340. https://doi.org/10.1016/0883-9026(92)90005-C

Laverty, K.J. (2001). Market share, profits and business strategy. Management Decision, 39(8), 607-618. https://doi.org/10.1108/EUM0000000005860

López-García, P., \& Puente, S. (2006). Business demography in Spain: Determinants of firm survival. Banco de España Research Paper No. WP-0608. Retrieved from:

http://www.bde.es/f/webbde/SES/Secciones/Publicaciones/PublicacionesSeriadas/DocumentosTrabajo/06/Fic/dt06 08e.pdf https://doi.org/10.2139/ssrn.901153

López-Gracia, J., \& Sogorb-Mira, F. (2008). Testing trade-off and pecking order theories financing SMEs. Small Business Economics, 31(2), 117-136. https://doi.org/10.1007/s11187-007-9088-4

Lotti, F., \& Santarelli, E. (2004). Industry dynamics and the distribution of firm sizes: A nonparametric approach. Southern Economic Journal, 70(3), 443-466. https://doi.org/10.2307/4135325

Martínez-Sola, C., García-Teruel, P.J., \& Martínez-Solano, P. (2014). Trade credit and SME profitability. Small Business Economics, 42(3), 561-577. https://doi.org/10.1007/s11187-013-9491-y

Mata, J., \& Portugal, P. (2002). The survival of new domestic and foreign-owned firms. Strategic Management Journal, 23(4), 323-343. https://doi.org/10.1002/smj.217

McAfee, R.P., Mialon, H.M., \& Williams, M.A. (2004). What is a barrier to entry?. The American Economic Review, 94(2),461-465. https://doi.org/10.1257/0002828041302235 
Mellahi, K., \& Wilkinson, A. (2004). Organizational failure: A critique of recent research and a proposed integrative framework. International Journal of Management Reviews, 5-6(1), 21-41. https://doi.org/10.1111/j.14608545.2004.00095.x

Modigliani, F., \& Miller, M.H. (1958). The cost of capital, corporation finance and the theory of investment. The American Economic Review, 48(3), 261-297.

Murphy, G.B., Trailer, J.W., \& Hill, R.C. (1996). Measuring performance in entrepreneurship research. Journal of Business Research, 36(1), 15-23. https://doi.org/10.1016/0148-2963(95)00159-X

Myers, S.C. (1984). The capital structure puzzle. The Journal of Finance, 39(3), 575-592. https://doi.org/10.2307/2327916

Myers, S.C.(2001). Capital structure. The Journal of Economic Perspectives, 15(2), 81-102. https://doi.org/10.1257/jep.15.2.81

Myers, S.C., \& Majluf, N.S. (1984). Corporate financing and investment decisions when firms have information that investors do not have. Journal of Financial Economics, 13(2),187-221. https://doi.org/10.1016/0304405X(84)90023-0

Nunes, P.M., \& Serrasqueiro, Z. (2012). Are young SMEs' survival determinants different? Empirical evidence using panel data. Applied Economics Letters, 19(9), 849-855. https://doi.org/10.1080/13504851.2011.607112

Ohlson, J.A. (1980). Financial ratios and the probabilistic prediction of bankruptcy. Journal of Accounting Research,18(1), 109-131. https://doi.org/10.2307/2490395

Petersen, M.A., \& Rajan, R.G. (1997). Trade credit: Theories and evidence. Review of Financial Studies, 10(3),661-691. https://doi.org/10.1093/rfs/10.3.661

Reid, G.C., \& Smith, J.A. (2000). What makes a new business start-up successful?. Small Business Economics, 14(3), 165-182. https://doi.org/10.1023/A:1008168226739

Reimsbach, D., \& Hauschild, B. (2012). Corporate venturing: An extended typology. Journal of Management Control, 23(1), 71-80. https://doi.org/10.1007/s00187-012-0151-1

Robb, A.M., \& Robinson, D.T. (2014). The capital structure decisions of new firms. The Review of Financial Studies, 27(1), 153-179. https://doi.org/10.1093/rfs/hhs072

Robinson, K.C. (1999). An examination of the influence of industry structure on eight alternative measures of new venture performance for high potential independent new ventures. Journal of Business Venturing, 14(2), 165-187. https://doi.org/10.1016/S0883-9026(97)00083-9

Rutherford, M.W., Coombes, S.M.T., \& Mazzei, M.J. (2012). The impact of bootstrapping on new venture performance and survival: A longitudinal analysis. Frontiers of Entrepreneurship Research, 32(12), Article 4, 498-513. Retrieved from: http://digitalknowledge.babson.edu/fer/vol32/iss12/4

Santarelli, E., \& Vivarelli, M. (2007). Entrepreneurship and the process of firms' entry, survival and growth. Industrial and Corporate Change, 16(3), 455-488. https://doi.org/10.1093/icc/dtm010

Saridakis, G., Mole, K., \& Storey, D.J. (2008). New small firm survival in England. Empirica, 35(1), 25-39. https://doi.org/10.1007/s10663-007-9049-9

Segarra, A., \& Callejón, M. (2002). New firms's survival and market turbulence: New evidence from Spain. Review of Industrial Organization, 20(1), 1-14. https://doi.org/10.1023/A:1013309928700

Serrasqueiro, Z.S., \& Nunes, P.M. (2008). Performance and size: Empirical evidence from Portuguese SMEs. Small Business Economics, 31(2), 195-217. https://doi.org/10.1007/s11187-007-9092-8

Sharma, A., \& Kesner, I.F. (1996). Diversifying entry: Some ex ante explanations for postentry survival and growth. TheAcademy of Management Journal, 39(3), 635-677. https://doi.org/10.2307/256658 
Shrader, R.C., \& Simon, M. (1997). Corporate versus independent new ventures: Resource, strategy, and performance differences. Journal of Business Venturing, 12(1), 47-66. https://doi.org/10.1016/S08839026(96)00053-5

Stearns, T.M., Carter, N.M., Reynolds, P.D., \& Williams, M.L. (1995). New firm survival: Industry, strategy, and location. Journal of Business Venturing, 10(1), 23-42. https://doi.org/10.1016/0883-9026(94)00016-N

Stinchcombe, A.L. (1965). Social structure and organizations. In J.G. March \& Rand McNally (Eds.), Handbook of Organizations (pp. 142-193). Chicago, IL: Rand McNally.

Vázquez-Rozas, E., Gómes, S., \& Vieira, E. (2010). Entrepreneurship and economic growth in Spanish and Portuguese regions. Regional and Sectoral Economic Studies: RSES, 10(2), 95-110. Retrieved from: http://www.usc.es/economet/reviews/eers1028.pdf

Westhead, P., \& Storey, D.J. (1997). Financial constraints on the growth of high technology small firms in the United Kingdom. Applied Financial Economics, 7(2), 197-201. https://doi.org/10.1080/096031097333763

Wilson, N., \& Summers, B. (2002). Trade credit terms offered by small firms: Survey evidence and empirical analysis. Journal of Business Finance and Accounting, 29(3-4), 317-351. https://doi.org/10.1111/1468-5957.00434

Zahra, S.A. (1993). Environment, corporate entrepreneurship, and financial performance: A taxonomic approach. Journal of Business Venturing, 8(4), 319-340. https://doi.org/10.1016/0883-9026(93)90003-N

Zahra, S.A., \& George, G. (1999). Manufacturing strategy and new venture performance: A comparison of independent and corporate ventures in the biotechnology industry. The Journal of High Technology Management Research, 10(2),313-345. https://doi.org/10.1016/S1047-8310(99)00012-7

Intangible Capital, 2018 (www.intangiblecapital.org)

Article's contents are provided on an Attribution-Non Commercial 4.0 Creative commons International License. Readers are allowed to copy, distribute and communicate article's contents, provided the author's and Intangible Capital's names are included. It must not be used for commercial purposes. To see the complete license contents, please visit https://creativecommons.org/licenses/by-nc/4.0/. 